\title{
Medieval Translation in the Light of the Polysystem and Rewriting Theories
}

\section{The Georgian Case}

\author{
Nino Doborjginidze \\ Professor, Ilia State University, Tbilisi, Georgia \\ nino_doborjginidze@iliauni.edu.ge
}

\author{
Nino Mataradze \\ Associate Professor, Ilia State University, Tbilisi, Georgia \\ nino.mataradze@iliauni.edu.ge \\ Elene Tatishvili \\ Associate Professor, Ilia State University, Tbilisi, Georgia \\ elene.tatishvili@iliauni.edu.ge
}

\begin{abstract}
This paper examines through the lens of translation studies (TS) the pattern of sociocultural and linguistic evolution to which medieval vernaculars of the Christian East adhered. It aims to contribute to discussions in medieval studies and Ts with regard to vernacular translations. The medieval Georgian tradition of translation is examined from the perspective of descriptivist translation theories, namely, in the light of Even-Zohar's polysystem and Lefevere's rewriting theories. The Georgian literary polysystem is viewed as part of a larger mega-polysystem of the Christian East, with Greek being at its centre. This explains parallels in the emancipation of vernacular languages. From the viewpoint of the rewriting theory, emphasis is given to the roles of professional circles, patronage and dominant poetics. The evolution of the Georgian translation tradition from free rendering to a higher concern for precision reflects the impact of different sociocultural factors, evidencing the validity of the mentioned descriptivist models.
\end{abstract}




\section{Keywords}

Medieval Georgian translation - vernacular languages - religious translation polysystems - rewriting theory

The eastern tradition of translation has been scrupulously addressed in medieval studies, with translation being regarded as a driving force in the evolution of vernacular languages and literatures. Similarities with regard to the approaches to translation enabled scholars to identify a certain regularity in the emancipation of local languages and literatures relative to those of dominant cultures. ${ }^{2}$ Modern translation studies (TS) assigns a similar role to translations, viewing them as 'agents of change' 3 and prioritizing their importance in terms of constructing, developing and shaping local languages and cultures. ${ }^{4}$

This paper seeks to examine the pattern of sociocultural and linguistic evolution to which vernaculars adhered from the perspective of Ts, specifically the polysystem and rewriting theories, through consideration of the Georgian

1 The article was prepared in the framework of the project supported by the Shota Rustaveli National Science Foundation (Nr DP2016_23).

2 S. Brock, "Aspects of Translation Technique in Antiquity," GRBS2O (1979), pp. 69-87; idem, "Towards a History of Syriac Translation Technique," in: Studies in Syriac Christianity, ed. R. Lavenant, Brookfield, VT, 1992, pp. 1-14; W. Boeder, "Identität und Universalität: Volkssprache und Schriftsprache in den Ländern des alten christlichen Orients," Georgica 17 (1994), pp. 66-84; N. Doborjginidze, "Die identitätsbildende Funktion der Sprache und Übersetzungsprobleme bei den altgeorgischen Exegeten," in: Muster und Funktionen kultureller Selbst- und Fremdwahrnehmung. Beiträge zur internationalen Geschichte der sprachlichen und literarischen Emanzipation, eds. Ulrike-Christine Sander

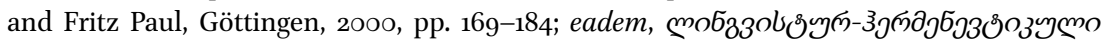

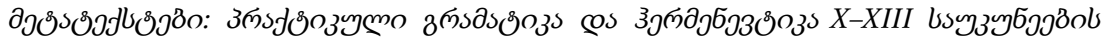

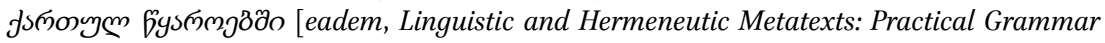
and Hermeneutics in the Tenth-Thirteenth-Century Georgian Sources], Tbilisi, 2012; cf. R. Copeland, "Rhetoric and Vernacular Translation," Studies in the Age of Chaucer 9 (1987), pp. 41-75; eadem, Rhetoric, Hermeneutics and Translation in the Middle Ages, Cambridge, 1991.

3 P. Burke and R. Po-Chia Hsia, "Introduction," in: Cultural Translation in Early Modern Europe, ed. Peter Burke and Po-Chia Hsia, Cambridge, 2007, pp. 1-4.

4 I. Even-Zohar, "Polysystem Studies," Poetics Today 11/1 (1990) (the monograph occupies the entire issue); L. Long, "Medieval Literature through the Lens of Translation Theory Bridging the Interpretive Gap," Translation Studies 3/1 (2010), pp. 61-77; A. Lefevere, Translation, Rewriting and Manipulation of Literary Fame, London, 1992; M. Tymoczko, "Translation in Twelfth Century France," New Comparison 1 (1986), pp. 7-27; eadem, "Translation, Ideology, and Creativity," Lingüistica Antverpiensia 2 (2003), pp. 27-45. 
case of medieval translations that were dominated by religious literature. We thus attempt to provide further evidence to support the recent 'turn towards history' in TS, ${ }^{5}$ and to contribute to the related debate on the tension between the historiographical approach maintained in medieval studies and the decontextualizing approach of Ts, which Carol O'Sullivan qualifies as "ultimately

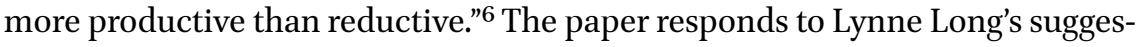
tion that "theories used in the modern discipline of Ts can in fact be usefully employed by medievalists and translation scholars" 7 and used "retrospectively on case studies for which it was not intended".

In modern translation studies, religious text translations are often studied from the standpoints of postcolonial critique and the theory of systems, ${ }^{9}$ while polysystem and skopos theories are suggested for medieval translations in general. ${ }^{10}$ The viability of studying medieval texts through the lens of Ts has been further demonstrated. ${ }^{11}$ The combination of the two perspectives is seen as "cross-fertilization," enriching both fields of study. ${ }^{12}$

We examine two stages in the history of the Georgian tradition of translating, spanning the period from the tenth through the twelfth century: the Athonite pre-Hellenophile and the post-Athonite Hellenophile, ${ }^{13}$ drawing

Burke and Hsia, Introduction, 2; G. L. Bastin and P. F. Bandia, "Introduction," in: Charting the Future of Translation History, ed. idem, Ottawa, 2006, pp. 1-10; R. Stanton, "The (M)other Tongue. Translation Theory and Old English," in: Translation Theory and Practice in the Middle Ages, ed. J. Beer, Kalamazoo, MI, 1997, pp. 33-46, at p. 35; Long, "Medieval Literature."

6 C. O'Sullivan,"Introduction: Rethinking Methods in Translation History," Translation Studies 5/2 (2012), pp. 131-138, at p. 133; see also C. Rundle, "Translation as an Approach to History," Translation Studies 5/2 (2012), pp. 232-240; idem, "Theories and Methodologies of Translation History: the Value of an Interdisciplinary Approach," The Translator 20/1 (2014), pp. 2-8; T. Hermans, "Response," Translation Studies 5/2 (2012), pp. 242-245; D. Delabastita, "Response," Translation Studies 5/2 (2012), pp. 246-248; P. St-Pierre,"Response," Translation Studies 5/2 (2012), pp. 240-242; Burke and Hsia, "Introduction"; Long, "Medieval Literature."

7 Long, “Medieval Literature," p. 62.

$8 \quad$ Ibid., p. 64 .

9 L. Long, "Introduction: Translating Holy Texts," in: Translation and Religion. Holy Untranslatable? ed. eadem, Clevedon, 2005, pp. 1-15, at p. 1.

10 Eadem, "Medieval Literature," p. 64.

11 For example, A. Reynders, "Middle Dutch Literary Studies and Translation Studies." Translation Studies 11/1 (2018), pp. 17-32.

12 Reynders, "Middle Dutch," p. 18.

13 Three main stages can be distinguished in medieval Georgian translation on the basis of

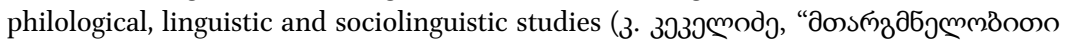

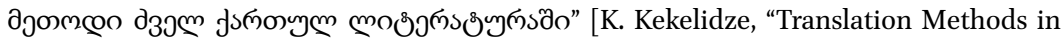

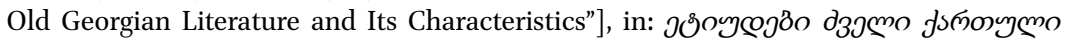


on the polysystem and rewriting theories. The latter have been developed as part of descriptive translation studies versus "source-oriented prescriptive

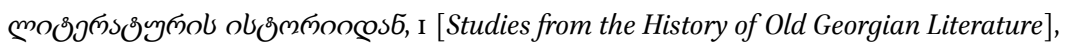

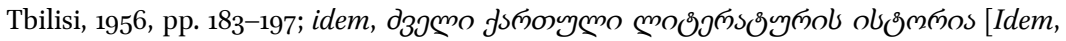

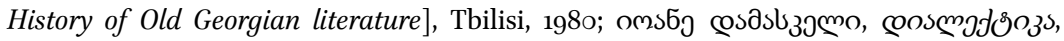

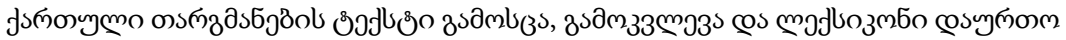
dsos nso3szsa [John of Damascus, Dialectics, Georgian translation prepared for publica-

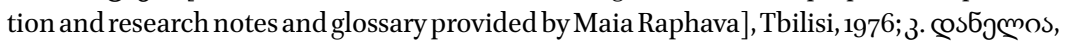

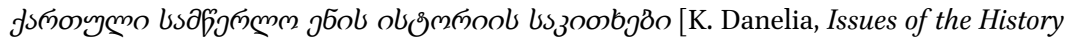
of Old Georgian Literary Language], Tbilisi, 1983; W. Boeder, "Die georgischen Mönche auf dem Berge Athos und die Geschichte der georgischen Schriftsprache," Bedi Kartlisa

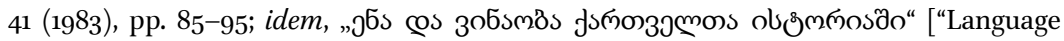

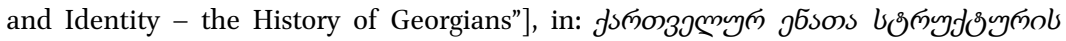
bszoobyzo, 7 [Questions of the Structure of Kartvelian Languages, 7] (1998), pp. 6o-81;

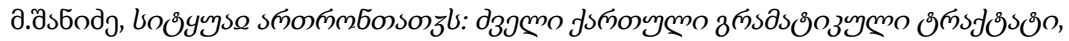

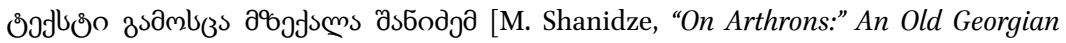
Grammar Treatise. The text prepared for publication by M. Shanidze], Tbilisi,

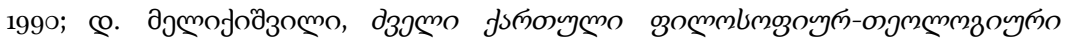

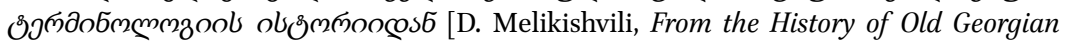
Philosophical and Theological Terminology], Tbilisi, 1999; Doborjginidze, "Die identitätsbildende Funktion"; eadem, "Einige Fragestellungen zur Herausbildung von Schriftsprachen im christlichen Osten am Beispiel des Georgischen," Le Muséon 121 (2008), pp. 193-212; eadem, Die georgische Sprache im Mittelalter, in: Sprachen und Kulturen des christlichen Orients, Bd. 17, eds. J. den Heijer, S. Emmel, M. Krause und A. Schmidt, Wiesbaden, 20o9; eadem, Linguistic and Hermeneutic Metatexts; eadem, "Religious Inculturation and Problems of Social History of the Georgian Language," in: Georgian Christian Thought and Its Cultural Context. Memorial Volume for the 125th Anniversary of Shalva Nutsubidze, eds. T. Nutsubidze, C. B. Horn, and B. Lourié, with the Collaboration of A. Ostrovsky (TSEC, 2), Leiden, 2014, pp. 327-343; eadem, "Language and Identity: Formation of Cultural Identity in Medieval Georgia," in: L'Arménie et la Géorgie en dialogue avec l'Europe. Du Moyen Âge à nos jours. Actes du colloque les relations interrégionales et la question de l'identité. Université Paul Valéry-Montpellier III. Les 27 et 28 septembre 2012, eds. I. Augé, G. Dédéyan, M. Dokhtourichvili, V. Barkhoudarian and I. Karaulashvili, Paris, 2016, pp. 173-187; eadem, "Medieval Georgian Projection of Religious Historiography of Late

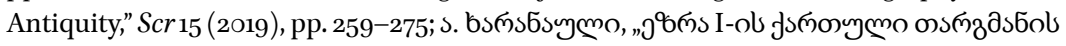

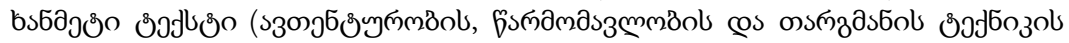
bszoobjöo)" [A. Kharanauli, "The Khanmeti Text of the Georgian Translation of Ezra I

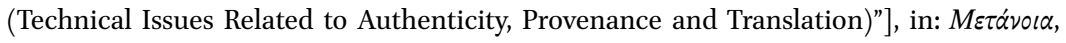

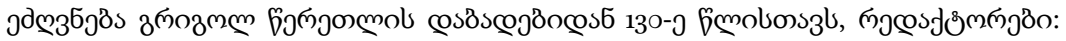

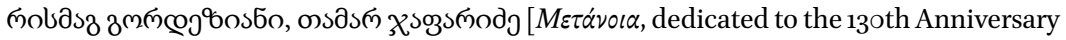
of Grigol Tsereteli, eds. R. Gordeziani and T. Japaridze], Tbilisi, 20o1, pp. 296-331; eadem,

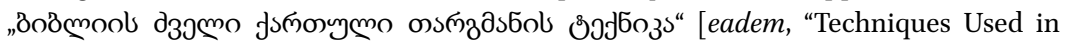

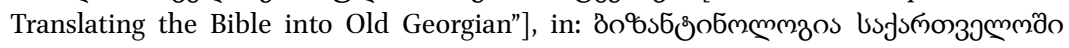

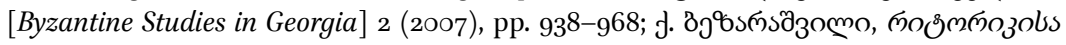

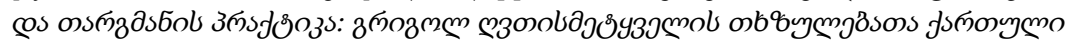

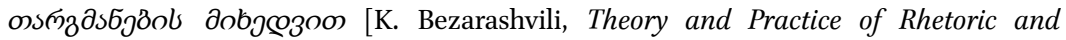
Translation: A Study of Georgian Translations of Gregory the Theologian's Writings], 
speculations", ${ }^{14}$ bringing into focus the status and sociocultural aspects of translated texts. Despite criticism of the polysystem theory, its applicability to the history of translation has been noted - according to Hermans, "using polysystem theory as a toolkit for historical research seems a more profitable line,"15 while according to Long, "the medieval context illustrates how useful polysystem theory can be as a framework for analyzing literary and translation trends within a cultural system". ${ }^{16}$ More specifically, the polysystem theory is applied as a general framework in order to analyze the criteria for selecting literature for translation, as well as the place secured in the Georgian polysystem by the translated texts and their influence on the development of original writing, including secular literature. Within the general frame of the polysystem theory, distinction is made between biblical and non-biblical (e.g. exegetical) texts. In its turn, the theory of rewriting, introduced together with the cultural turn of the 1980 , is used to allow a more detailed examination of factors linked to professionals within the literary system, patronage from outside the literary system (including ideological, economic and status aspects), and the dominant poetics ${ }^{17}$ with respect to medieval Georgian religious translations.

The period in the history of Georgian translation addressed in this paper was marked by efforts to make Georgian a functional and qualitative equal

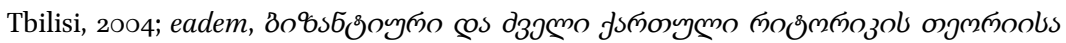

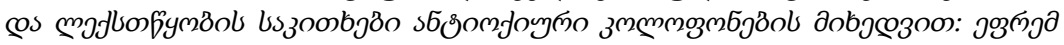
$\partial_{30}$ 的 [eadem, The Problems of Byzantine and Old Georgian Rhetorical Theory and Versification According to the Colophons of Antioch: Ephrem Mtsire], Tbilisi, 2012;

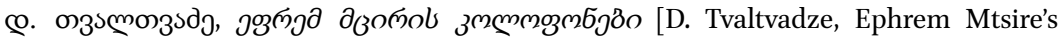

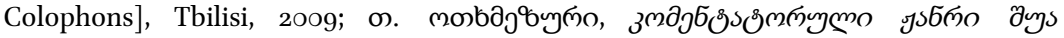

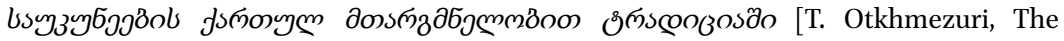
Commentarial Genre in the Georgian Translation Tradition], Tbilisi, 2011. The first is believed to have started after the declaration of Christianity as official religion in Georgia in the fourth century and continued to the tenth century. It is described as "spontaneous," lacking the conceptualization of translating approaches and normative use of lexical and grammatical equivalents in the target language. The focus was naturally placed on biblical and liturgical texts, followed by apophthegmatical and exegetical texts, mainly translated from Greek, Syriac, Arabic and Armenian. The main scholarly centres of the period were the Lavra of Mar Saba near Jerusalem, the monasteries in Palestine and Syria and, from the end of the eighth century, monasteries in the Tao Klarjeti province that was south-west Georgia at that time, and is now part of Turkey. G. Toury, "A Rationale for Descriptive Translation Studies," Dispositio 7/19-20-21, The Art and Science of Translation (1982), p. 34; T. Hermans, Translation in Systems: Descriptive and System-Oriented Approaches Explained (Translation Theories Explored), London, 1999/2014, pp. 7-16.

15 Hermans, Translation in Systems, pp. 102-117.

16 Long, "Medieval Literature," p. 67.

17 Lefevere, Translation, Rewriting and Manipulation. 
with Greek, the latter enjoying the status of privileged language. As is known, the principle of the hierarchy of languages, which was firmly established in Christendom at the time, also implied the topos of Greek as a language of philosophy and rhetoric vs. Georgian as an inferior language. Sociolingustic studies on medieval translation point out the effect of translating practices on the legitimization of vernacular languages and the function of Georgian. Two major stages have been identified in the context of making Georgian an equal to Greek: those of functional and qualitative legitimization. By the period examined in this paper, the problem of functional inequality had largely been overcome: Georgian had become the language of liturgy, and the core texts used in ecclesiastical services had already been translated. The challenge was to ensure qualitative legitimization, in other words, advancement of the expressive potential of the language. ${ }^{18}$

The translations made at the time allow us to consider the pre-Hellenophile and Hellenophile translation schools within a broader context, namely, the polysystems characteristic of Eastern Christendom that were formed as part of respective national agendas with the support of "core groups of learned men, who were the bearers of culture."19

The pre-Hellenophile period in the history of Georgian translation began in the tenth century with the conception of a translation project by the Georgian Athonite Fathers, most notably Euthymius the Athonite (Ekvtime Atoneli). ${ }^{20}$ The undertaking is legitimized by a scene from his Life according to which the young Euthymius, having been raised in Constantinople, miraculously acquired the faculty to speak fluent Georgian after he was visited by the Virgin, who cured him of a grave disease and instructed him to speak Georgian. Another episode from the Life conceptualizes translation as a means of developing the target literature, with John the Athonite (Ioane Atoneli) instructing his son Euthymius to undertake a translation project: "The land of Kartli is

\footnotetext{
18 Doborjginidze, "Religious Inculturation," pp. 337-341.

19 Doborjginidze, "Language and Identity," p. 173.

20 Euthymius the Athonite was the founder of the Athonite literary school. Raised in Constantinople, he later became a monk at the Monastery of Great Lavra on Mount Athos and then served as hegumen of the Iviron Monastery. His translations include over one hundred religious texts. For a detailed list of translations by Euthymius, see Doborjginidze, Die georgische Sprache, pp. 199-220.
} 
deficient in scholarship and lacks many books. I can see you are endowed from God. Endeavour to multiply the talent given to you by God."21

\subsection{Polysystem Theory}

According to Itamar Even-Zohar, literature, and translated literature in particular, is viewed as element of a broader sociocultural polysystem, or a conglomerate, interacting with other systems such as artistic, political and religious ones. ${ }^{22}$ National polysystems can, in turn, become part of "mega-polysystems" comprising several national polysystems that undergo constant evolution through the influence of diverse factors. ${ }^{23}$ Medieval Eastern Christendom, with Greek culture as its nucleus and the peripheries dominated by vernacular cultures such as Syriac, Georgian, Coptic, Ethiopian, Slavic and Gothic, ${ }^{24}$ can be viewed as one structured, hierarchized mega-polysystem. The systematic character of relations between the nucleus and the peripheries is suggested by the similarity of the 'socio-semiotic' activities. All vernacular cultures of the Christian East responded similarly to two chief arguments advanced by the central Greek authority - the poverty of the vernacular language and the threat of heresy caused by arbitrary translations of holy texts. The response was a series of efforts towards the functional and qualitative legitimization of local languages. ${ }^{25}$

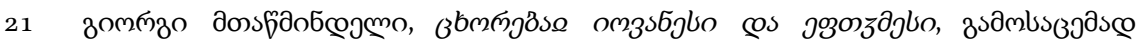

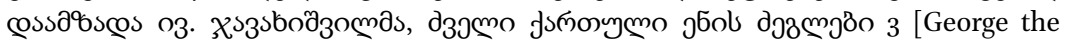
Hagiorite (Giorgi Mtatsmindeli), The Life of John and Euthymius, prepared for publication by I. Javakhishvili (Literary Texts in Old Georgian Language, 3)], Tbilisi, 1946, p. 28.

22 M. Shuttleworth, "Polysystem Theory," in Routledge Encyclopedia of Translation Studies, ed. Mona Baker, London, 2001, pp. 176-179.

23 Even-Zohar, "Polysystem Studies," pp. 23-24.

24 Doborjginidze, "Die georgische Sprache," pp. $5^{-13}, 46-51$. It is commonly accepted that Slavic is the only "non-natural" language of those in Eastern Christendom created for the purpose of translating the Bible. See A. Issatschenko, Mythen und Tatsachen über die Entstehung der russischen Literatursprache, Wien, 1975, pp. 5-80. Gothic is assigned to the Eastern Christian sociocultural mega-polysystem for being the only Germanic language in which the Bible was translated from Greek and for its proximity to Slavs; B. Luiselli, "Inkulturativer und akkulturativer Prozeß der Christianisierung: Die Entstehung der nationalen Literaturen und der Latein sprechenden Eliten in Westeuropa," in: Muster und Funktionen kultureller Selbst- und Fremdwahrnehmung. Beiträge zur internationalen Geschichte der sprachlichen und literarischen Emanzipation, eds. U.-C. Sander and F. Paul, Göttingen, 2000, pp. 146-168.

25 Doborjginidze, "Die identitätsbildende Funktion"; eadem, "Einige Fragestellungen"; eadem, "Religious Inculturation"; Luiselli, "Inkulturativer und akkulturativer." Even-Zohar presents the case of medieval Central and Western Europe as a single polysystem dominated by the literatures written in Latin and comprising vernacular literatures as peripheries. The collapse of the mega-polysystem in the eighteenth century resulted in 
By attaching an important status to translation, Even-Zohar upgraded translation from the secondary position it had been assigned by literary critique, as can be evidenced by medieval literary and translation practices, including in Georgian. The central status acquired by translation in the Georgian polysystem was defined in particular by the level of development of the target literature, as well as its specific genre. The foundation of a Georgian Monastery on Mount Athos in the tenth century complemented an overall national agenda of achieving cultural and linguistic equality with Greek, and Georgian translations began to play an essential role in the national polysystem, triggering its dynamic evolution. As evidenced by the Life of Euthymius, when the Athonites began their activity, the Georgian polysystem was deficient, especially given the importance of religious literature at the time. The aspirations of Georgian scholars appeared to be inherently ambivalent, as on the one hand they implied alignment with the advanced Greek culture, while on the other, a willingness to retain independence on an equal footing. ${ }^{26}$

The selection of core texts was dictated by the urgent necessity to fill the gap that hindered alignment with the Greek world. This explains why Euthymius the Athonite is, in his Vita, referred to as "the Enlightener of the Georgians" and his deeds are compared to John Chrysostom's. ${ }^{27}$ During the early stage of his activity on Mount Athos, Euthymius the Athonite translated biblical books which had either not been rendered into Georgian (e.g. John's Revelation), or comprised part of the core texts and had to be retranslated due to having been "ill-rendered and hastily and superficially translated" (the Psalms and the Gospels).

Translations by another representative of the Athonite school and the biographer of John and Euthymius, George the Hagiorite (Giorgi Mtatsmindeli), ${ }^{28}$ further expanded the Georgian corpus of core religious texts, while at the same

the development of local polysystems (Even-Zohar, "Polysystem Studies," pp. 23-24). In Eastern Christendom these processes started much earlier than in the West. On parallels and differences between the Eastern and Western Christian topoi, also see Doborjginidze, "Religious Inculturation."

26 Doborjginidze, "Language and Identity."

27 George the Hagiorite, The Life of John and Euthymius, p. 15, 5.1; p. 28, 48.1.

28 George the Hagiorite (or Athonite), an eleventh-century Georgian cleric, scholar and translator, was a hegumen (Father Superior) at the Iviron Monastery on Mount Athos between 1044 and 1056. Educated in Constantinople, George the Hagiorite revised Euthymius' translation of the New Testament, which itself was a retranslation, without making any changes to the Revelation of John and the Psalms, translated by Euthymius for the first time. He also rendered a full version of Big Synaxarion, Big Breviary, Big Octoechos, and the Lenten Triodion, which Euthymius had translated, but in a short form. His other translations include Basil's Hexaemeron, Gregory of Nyssa's De hominis 
time initiated a major revision of biblical as well as other religious texts that had allegedly been "distorted" by copyists.

He brought to light from the depth of ignorance books that were lacking in Georgian and unknown to us, and in the furnace of his blessed mind forged books translated at an earlier time that were either rendered inappropriately or spoiled over time by imprudent users. He also completed books translated by our holy father Euthymius which, due to the latter's shortage of time, had not been translated in full and were presented as abridged versions. He [George the Hagiorite] compared other books to the Greek [sources], completed them and relieved them of awkward phrases and other impurities. ${ }^{29}$

The need to justify the retranslation was not specific to Georgian scholars: more or less similar arguments can be found in other literatures of the megapolysystem of Eastern Christianity.

As a contemporary of Georgian Hellenophile scholars, George the Hagiorite was familiar with their priorities. His version of the New Testament became canonical, and thus acquired a central position in the Georgian polysystem a status it retains to the present day. Having achieved a balance between literal and reader-oriented approaches, this version met translational and social norms. The translator's purpose and strategy are illustrated by his own comment: "And you who copy [this text], inscribe it without change: Do not add to it, do not subtract. We made the additions and omissions as the language required, and as was needed."30

opificio, Gregory Thaumaturgus' Credo, as well as works by Athanasius of Alexandria, Patriarch Photios and Theodore the Studite.

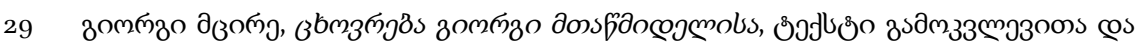

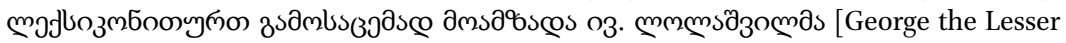
(Giorgi Mtsire), The Life of George the Hagiorite, prepared for publication and research notes and a glossary provided by I. Lolashvili], 1994, pp. 194-195, 210. Cf. Philoxenus of Mabbug's arguments for the revision of Peshitta's translation of the New Testament in the Syriac tradition were that: "the original translators 'had made mistakes in many things, whether intentionally or through ignorance' [...]Those who have translated books from Greek into Syriac by not bothering to preserve the exactitude of the words employed by the Greeks or the precision of the sense, have gone astray and put what took their fancy, or some word they considered to be in current use in Syriac. They did not realize that, had they translated using these neologisms ..., they would soon have become just as familiar as the older terms" (Brock, "Towards a History," pp. 8-9). 
Translated from a language held in higher prestige from cultural and literary standpoints, religious texts formed the core of the polysystem and acted as a catalyst for the development of original literature of different genres, thus shaping the trend of Georgian culture. Apart from introducing several new genres into the national polysystem, translation also facilitated functional legitimization of the status of Georgian as a language of the Bible and liturgy, similar to Greek, and prepared the ground for qualitative legitimization of Georgian. ${ }^{31}$

\section{$2.2 \quad$ Rewriting Theory}

Professional circles and patronage, as foregrounded in the rewriting theory, largely defined trends in the national polysystem during the period in question. The most influential figures at that time, ${ }^{32}$ whom we could qualify as professionals according to Lefevere's theory, mainly included religious scholars - leading agents of translation projects. According to Georgian historical records, the translators active in the Georgian monastery on Mount Athos enjoyed royal patronage, which raised their project to national level. Remarkably, rubrics concerning the importance that tenth and eleventh-century Georgian kings assigned to translation recur in the lives of the Athonite fathers. Prince David Kuropalates (r. 961-1001), who for his outstanding service was rewarded by the Byzantine Emperor with lifetime rule of certain lands, built a Georgian monastery on the granted lands and established a library for the new complex. ${ }^{33} \mathrm{By}$ translating core religious texts, the Georgian monks became actively engaged in implementing the political and diplomatic agendas of the Georgian royal court. The keen interest in translation projects taken by the kings is further illustrated by the eulogies of royals found in the translators' comments and the Lives.

It is known that Athonite monks sent translations to the royal court, and Georgian kings participated in making decisions regarding revisions and new translations. Euthymius the Athonite sent his ${ }^{34}$ translations to King David Kuropalates, who was "filled with joy" and thanked God for sending Georgians

31 The earliest attempts towards functional legitimization in the Georgian literary tradition can be dated to the late fifth century when biblical books and necessary liturgical texts began to be translated. Similar processes are evident in other countries of Eastern Christianity, even at an earlier stage (Doborjginidze, "Die identitätsbildende Funktion"). Cf.: the "core groups of learned men, who were the bearers of the culture" (Doborginidze, "Language and Identity," p. 173).

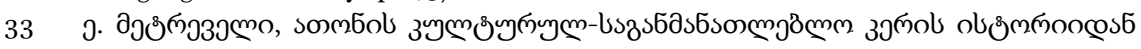
[E. Metreveli, From the History of the Cultural and Educational Centre on Athos], Tbilisi, 1996, pp. 3-40.

Doborjginidze, “Linguistic and Hermeneutic Metatexts," pp. 7-8 n. 12. 
a new Chrysostom. The Georgian royal families also sought advice from the Athonite monks regarding the canonicity of certain religious texts. For example, between 1060-1065, before undertaking a church reform, King Bagrat IV of Georgia (r. 1027-1072) invited to his court George the Hagiorite, who had by then already translated religious texts. Along with other changes, the reform also implied the provision of revised editions of biblical books and core liturgical and canonical texts. Launched during the lifetime of George the Hagiorite, the reform culminated with the 1104 Council of Ruis-Urbnisi convened by King David IV of Georgia (David Aghmashenebeli, or David the Builder; r. 1089-1125).

The notion of cultural and political legitimization of Georgian language united secular and religious authorities under a common agenda. Winfried Boeder was the first to focus specifically on the political importance of the Georgian monastery on Mount Athos, viewing translation as a driving force of the development of the language and the country alike. This was later attested by the study of Greek and Georgian colophons from Mount Athos. ${ }^{35}$

The ideology governing the translation agenda also dictated the translation approach. The social status of the selected texts, as well as related sociocultural norms, was geared to the expectations of the target readership and the acceptability of the texts. The strategy of free translation employed by the translators, primarily by Euthymius, was driven by a desire to fill the gap within a limited period, producing readable, fluent translations, and thus bringing core texts closer to their readers. The repertoire of the translation techniques Euthymius used included simplification, extraction, abridgement, interpolation, addition and compilation in order to create more easily accessible versions for "the immature and unintelligent" congregation. ${ }^{36}$ By "nationalizing" and "Georgianizing" Byzantine culture, he was to prepare readers hitherto unaccustomed to logical abstractions for the understanding of complex theological thoughts. ${ }^{37}$

35 Boeder, "Die georgischen Mönche"; Doborjginidze, "Religious Inculturation," p. 327; ९.

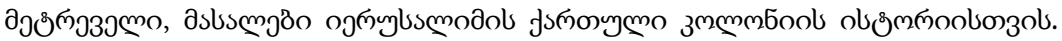
XI-XVII bsy3 Jerusalem. From the Eleventh through the Seventeenth Century], Tbilisi, 1962. A vivid example is the appreciative account of the Athonites' activities included in their Lives: “[...] day and night, [Euthymius] harvested the sweet honey of the divine Books, with which he sweetened our language and church" (George the Lesser, The Life of George the Hagiorite, p. 48).

36 Tbilisi, Georgian National Centre of Manuscripts, Ms A-11o, fol. 3.

37 Bezarashvili, "Theory and Practice," pp. 22-23. Bezarashvili qualifies the free approach used by Euthymius as compilational and as "expository translation" whose principles reverberated with the dominant Byzantine literary processes of the time. She also relates the approach to Nida's dynamic equivalence (ibid., pp. 319-322). 
While the free translating approach employed by Euthymius was tailored to the needs of his contemporary readership, it also synchronized with models dominant in the source (i.e. Byzantine) rhetoric of the time, including the art of composition and improvization, the addition of connecting and complementary narratives, as well as the use of biblical paradigms for rhetorical purposes. ${ }^{38}$

The free approach was mainly applied to theological texts rather than the Bible itself, which was regarded as sacred, thus requiring a greater degree of faithfulness. ${ }^{39}$ The strategy used by Euthymius can best be manifested by his translation of Gregory the Theologian's works, which was characterized by major as well as minor textual deviations, including the addition of extensive informative interpolations, abridgement, compilation, quantitative extensions, and other simplifications. ${ }^{40}$

The use of this approach was common in other polysystems of the preHellenophile period, e.g. Greek-to-Syriac renderings of biblical and nonbiblical texts from the pre-Hellenophile period. According to Sebastian Brock, early Syriac translators attempted to bring the text to the reader, which makes the translations expository and tendentious. ${ }^{41}$ Basil's homilies were expanded by almost half in Syriac, while the wording of biblical quotations they included were in line with the early Syriac version of the Bible, as such adapted to the target language norms and the expectations of the intended reader. ${ }^{42}$

The Georgian Athonite literary movement was characterized by intense activity in rendering Greek works into Georgian. Despite the fact that translations from this period were attuned to target language norms and were free from source language interferences, this movement prepared the ground for Hellenophilism in Georgian literature, and was associated with the Georgian monks active in the centres of Black Mountain, Antioch and Gelati in Georgia.

38 Bezarashvili, “Theory and Practice," pp. 96-97.

39 Cf:: "Indeed, I not only admit, but freely proclaim that in translation [interpretatione] from the Greek - except in the case of the Sacred Scripture, where the very order of the words is a mystery - I render not word for word, but sense for sense" (Jerome, Ad Pammachium, 57; trans. Kathleen Davis, in: The Translation Studies Reader, ed. L. Venuti, and edition, New York, 2004, pp. 21-30, at p. 23).

40 Bezarashvili, "Theory and Practice," pp. 425-459.

41 Brock, "Towards a History," pp. 4-5. However, the advancement of Hellinophile trends, which began in Syria no later than the mid-fifth century, led to the opposite approach - to bring the reader to the text: the translations of biblical quotations were no longer oriented towards the Syriac Bible, but closely adhered to the Greek source: "Earlier translations can essentially be seen as bringing the source text to the Syriac reader, whereas with later ones the movement is the reverse, drawing the reader towards the original" (Brock, "Towards a History," p. 4).

Brock, "Aspects," p. 75; Brock, "Towards a History," p. 11. 


\section{Hellenophile Stage: Revisionism towards Source Orientation}

The early eleventh century saw a transition from the pre-Hellenophile period to the early stage of Hellenophilism in the Georgian tradition of translation. The period coincided with the activity of Georgian monks at Black Mountain in Antioch, which, having been reincorporated into Byzantium, served as a major cultural centre of Christendom. Early translations by one of the representatives of this school, Ephraim the Lesser, adhered to the Athonite principles, while his later renderings sought more accuracy and were provided with commentaries in the margins in place of the interpolations that were widely applied in the pre-Hellenophile Athonite period. Translations by other representatives of the school, most notably those by Arsen of Ikalto (Arsen Ikaltoeli $)^{43}$ and John of Petritsoni (Ioane Petritsi), ${ }^{44}$ demonstrated a more obvious shift from the free rendering typical of the pre-Hellenophile school of translation to an alignment with the Greek original and an increased concern with precision.

\subsection{Polysystem Theory}

The shift to the new stage brought revisions to the Georgian polysystem. If Even-Zohar's typology is applied, Ephraim the Lesser's translations can be regarded as transitional between the second and third stages, when the nucleus of the polysystem is still in the process of formation, and genre diversification is under way - both in translation and original writing. This period saw the formation of a new type of translated corpora according to the best Byzantine practices, the development of exegetical commentary, and the systemitazation

43 Arsen of Ikalto, a contemporary of John of Petritsoni, was a grammarian, translator, philosopher and writer educated at the Academy of Mangana in Constantinople. His teachers were Michael Psellos and John Nomophylax. Arsen spent several years in the Black Mountain under the guidance of Ephraim the Lesser. Upon his return to Georgia, he first joined the Gelati Academy and then, with royal support, founded a new academy at the Ikalto Monastery where he served as Rector. For Arsen's translations of theological and philosophical texts see Kekelidze, History, pp. $273^{-284}$.

44 John of Petritsoni, an eleventh-twelfth-century Georgian theologian, translator and philosopher, was educated in Constantinople under the guidance of Michael Psellos and John Italos. Adhering to the Neo-Platonist ideas of his teachers, he confronted the conservative stance of Byzantine ecclesiastical officials and returned to Georgia, only to find it completely devastated by incessant Seljuq raids and disastrous earthquakes. He was compelled to leave Georgia, and settled in the Petritsoni Monastery in Bulgaria. John's philosophical views were not completely shared either in his homeland or in Bulgaria. His activities were fully appreciated under King David IV of Georgia, who invited him to the Gelati Academy along with other scholars. On John's translations of historical, ascetic and philosophical texts see Kekelidze, History, pp. 284-305. 
and expansion of terminology in Georgia. Apart from ascetic and homiletic (Basil of Caesarea and Gregory the Theologian) and metaphrastic literature (Symeon the Metaphrast), Ephraim the Lesser translated theological and philosophical texts, namely: "The Source of Knowledge" by John of Damascus, "The Areopagetic Corpus" by Maximus the Confessor, and "Meditation on Church Matters or Commentary on the Liturgy" by Patriarch Germanus. ${ }^{45}$ Translation of philosophical literature, for its part, encouraged the creation of original philosophical texts. Particularly noteworthy are John of Petritsoni's commentaries in his translation of Proclus Diadochus' "The Elements of Theology", which offer deep philosophical insights.

Revision of the polysystem was complemented by advancement of the language itself and its enrichment with new terms and conceptual vocabulary, which differed from the "natural" language of the Athonites and even that of George the Hagiorite's balanced translations. Shifting attitudes towards "exterior wisdom" (including Hindu and Persian writings) in secular literature culminated with the twelfth-century epic poem "Vepkhist'q'aosani" ("The Knight in the Panther's Skin") by Shota Rustaveli, which reflected Neo-Platonist ideas. The change was also marked by neutralization of negative connotations of the terms 'Hellenic' and 'philosopher. ${ }^{46}$

\subsection{Rewriting Theory}

Professional circles, the importance of which has been highlighted in Lefevere's triadic model, played an essential role in defining the way the Georgian polysystem was to evolve. The fact that Ephraim's efforts were driven not only by an ideological agenda, but also by professional policy, is indicated by the support he received from other representatives of the Black Mountain centre, ${ }^{47}$ who called on him to align previous translations to the Greek originals.

Although the post-Athonite Georgian scholars, unlike the Athonites, were dispersed across different monastic centres, they still managed to coordinate their translation activities, which were in full consonance with the royal ideology of the time. In one of the introductions, Ephraim the Lesser noted that he had waited twelve years for George the Athonite's translation of Basil of Caesarea's "Asketikon".

Royal patronage continued into the Hellenophile period, which coincided with the political and cultural advancement of Georgia. The Georgian monks and scholars at the Black Mountain centre, who enjoyed the generous patronage

\footnotetext{
45 Bezarashvili, “Theory and Practice," p. 9.

46 Ibid., pp. 110-123.

47 Ibid., p. 339 .
} 
of King David IV of Georgia, were invited by the royal court to establish centres of learning within Georgia and ultimately founded the well-known academies of Ikalto and Gelati, the latter being eulogized as 'a Second Jerusalem' and 'a New Athens' in medieval Georgian chronicles. These royal efforts were also part of a broader national agenda that included church reform.

Arsen of Ikalto justified his retranslation of the Canons by Andrew of Crete (two previous translations of which contained numerous deletions, replacements and additions) as being instructed by the royal commission he was to obey:

Therefore, I, worthless slave, [...] the humble monk Arsen, [...] dared to translate them for the third time with precision, as has been [...] composed by St Andrew in Greek, upon the instruction and commission of King David of the Apkhaz, Georgians, Rans and Kakhs [...].48

The high status accorded to Arsen of Ikalto by the royal authorities is demonstrated by the fact that he was invited by King David IV as an authority to help settle a dispute between Armenians and Georgians. Another example of royal recognition is the "understanding and assistance" from King David ${ }^{49}$ that was enjoyed by John of Petritsoni, who at the same time complained about the lack of support from Georgians.

Hellenophile efforts to bring Georgian translations closer to the Greek sources were fully consistent with the country's political and cultural agenda of the time, and entailed a revision of the poetic norms of the pre-Hellenophile period. As Lefevere claimed, ideological differences ultimately lead to changes in poetics: "On every level of the translation process, it can be shown that if linguistic considerations enter into conflict with considerations of an ideological and/or poetological nature, the latter tend to win out". ${ }^{0}$ Once functional legitimization had been achieved, a qualitative legitimization of Georgian language and its equalization with Greek was on the agenda. This entailed the revision of poetics, which also influenced the manner in which translations were made, subsequently leading to enrichment of the language with new concepts and the expansion of its instrumental potential and expressiveness. The transition

48 St Catherine's Monastery, Mount Sinai, ms Sin. 70/57, fols. 131v-132v, in: H. Mapp, Описание грузинских рукописей Синайского монастыря [N. Marr, Description of Georgian manuscripts of Mount Sinai], Moscow - Leningrad, 1940, pp. 203-204.

49 Kekelidze, History, p. 286.

$5^{\circ} \quad$ Lefevere, Translation, Rewriting and Manipulation, p. 39. 
to literal translation, which is acknowledged as a benchmark in the Middle Ages, encouraged not only diversification of genres within the target polysystem, but also differentiation of styles.

Along with translation of new texts using a literal approach, Ephraim undertook the revision of pre-Hellenophile translations. One vivid example is the retranslation of Gregory the Theologian's works, which had initially been translated by Euthymius. Comparative analysis of the two versions reveals the differences between pre-Hellenophile and Hellenophile translational approaches and the accompanying sociocultural transformations. Unlike free, "expository" translation in Brock's terms, Ephraim's "mirror" translations, which represent formal equivalence, are rich in morphological, lexical and syntactic calques. ${ }^{51}$

By translating philosophical texts, John of Petritsoni sought not only to establish a Georgian philosophical school, but to elaborate the language of philosophy, including its terminology and style. His works abound with new terms - borrowings and etymological calques - which he adapted to Georgian grammatical norms. They are characterized by an even greater adherence to the source language word order. Unlike Ephraim, who furnished his work with metatexts that explained the reasons behind the retranslation, and simultaneously acted as a token of modesty, showing respect to previous translators, John of Petritsoni did not see the need for adding commentaries to his translations. ${ }^{52}$

In Georgian medieval studies, transition from the free to literal approach in the Georgian translation tradition has been explained by a hermeneutical principle - the progression from simple to complex (from "infant" to "mature"). This stage-by-stage natural development was based on the principle of succession in the evolution of Georgian literature. ${ }^{53}$ Hence translation is seen as a topos for the 'enlightenment' of Georgian language and its alignment with Greek. ${ }^{54}$

Applied to translation, this model is fully consistent with the framework of rewriting theory, according to which poetics is driven by ideology. As observed by Maximus of Tyre, people can be compared to "infants" "not yet ready" for

$5^{1} \quad$ Brock, "Aspects."

$5^{2}$ Doborjginidze, "Linguistic and Hermeneutic Metatexts," p. 9 o.

53 Otkhmezuri, "Commentarial Genre," p. 223; Doborjginidze, "Linguistic and Hermeneutic Metatexts," p. 163 .

54 Doborjginidze, "Linguistic and Hermeneutic Metatexts," p. 146. Cf. Goethe's three categories of translation (a plain prose translation, parodistic translation and the translation, the goal of which is to "achieve perfect identity with the original") discussed in relation with Syriac translation by Brock, "Towards a History"; J. W. von Goethe, "Translations" [orig. Übersetzungen], trans. S. Sloan, in: The Translation Studies Reader, ed. L. Venuti, 2nd edition, New York, 2004, pp. 64-66. 
"solid food." ${ }^{5}$ It is with this principle that Ephraim the Lesser explained the use of free translation by his predecessors in the pre-Hellenophile stage:

He [Euthymius] would feed the infancy of our people with milk and herbs [...], as he had learnt this from Paul, and would dilute the strong, full-bodied wine of the Theologian's book with spiritual waters, expanding the laconic word of the preacher for the feeble, as our people were then feeble and immature. Therefore, he would dilute the translation with his holy words. ${ }^{56}$

In conceptualizing the poetics of early Athonite translation tradition, Ephraim describes Euthymius' effortless Georgian and the "beautiful" evangelical simplicity of his translations, as opposed to laconicity and "figurativeness." ${ }^{n 7}$ The "beauty" of translation implied clarity of thought, stylistic simplicity, fluency and compliance with the norms of Georgian language.

Being acquainted with adapted translations of theological texts made during the pre-Hellenophile period, the Georgian reader was ready to accept translations made with greater scholarly precision and marked with a 'grammarian and philosophical' style. ${ }^{58}$ Ephraim described Euthymius' translation as targeting the masses, and his own as aiming for the educated..$^{59}$ The new poetics, dubbed as "foreign to the uneducated" by John of Petritsoni, would gradually lose its quality of "foreignness" and become more "natural" 60 to the target readership.

Notably, functional and qualitative emancipation was not only a Georgian topos: an increased concern for precision characterized all the polysystems that made up the mega-polysystem of Eastern Christendom. Examples include the revision of the second-third-century version of the Syriac Bible in 507-508 by Philoxenus of Mabbug, who noted his concern regarding the inaccuracy of Syriac terminology when compared with the Greek; the retranslation of the Bible by Thomas of Harqel in 616, again with the aim of achieving greater precision; the retranslation of the Armenian Bible from Greek, finalized by the Armenian Bishop Nerses of Lambron in the twelfth century; the launch

55 1Cor 3:1-2; on this thesis of Maximus of Tyre as reflected in Ephraim the Lesser's translationrelated metatexts, see Doborjginidze, "Linguistic and Hermeneutic Metatexts," pp. 52-53.

56 Doborginidze, "Linguistic and Hermeneutic Metatexts," p. 162.

57 Bezarashvili, "Theory and Practice," pp. 315-318.

58 Bezarashvili, "Theory and Practice," p. 12. Ephraim's translations were not unanimously accepted; they even provoked harsh criticism due to his preference for precision over fluency. Some of his comments sound apologetic. See eabid., pp. 124-125.

6o Doborjginidze, "Linguistic and Hermeneutic Metatexts," pp. 9o-91. 
of the 'correction of books' by Patriarch Euthymius in Slavic countries; and the re-examination of translations used in the Eastern Slavic domain by the Metropolitan of Moscow in the fourteenth century. Presenting vernacular languages as "poor" languages of Eastern Christendom meant that they needed to be expanded through translation, and their technical terminology developed. ${ }^{61}$

\section{Conclusions}

Application of the descriptive model, and specifically the polysystem and rewriting theories to the study of medieval Georgian translation tradition proved useful for understanding the interaction of literary and socio-cultural processes in Georgia and in Eastern Christendom in general, as well as confirming the generalizability of modern descriptive theories. Driven by the overarching goal of enlightenment and emancipation, each stage in each polysystem that comprised the Eastern mega-polysystem was marked by a 'microideology' consistent with the specific needs and circumstances of the time.

If viewed through the lens of the polysystem theory, medieval national polysystems of the Christian East that displayed similar patterns in terms of their approaches to translation, mainly from Greek, can be considered as part of an eastern mega-polysystem. If we follow the pre-Hellenophile and Hellenophile traditions discussed above, we see that after the creation of a corpus of fundamental religious texts, translations acquired a central status in Georgian, as well as in the other polysystems in question, thus encouraging genre diversification. The selection of texts for translating and retranslating at each stage, as well as the status acquired by the translations in the polysystem, were defined by the level of development of the target literature.

In terms of the rewriting theory, Georgian medieval translating practices serve as further evidence of the convergence of factors associated with professional circles, patronage and poetics. Medieval Georgian translators' activities were markedly systematic and consistent, and enjoyed vigorous royal support during both the pre-Hellenophile and Hellenophile stages. Developed by the joint efforts of professionals and royal authorities, the national agendas, with translation at their core, aimed for functional legitimization and later, qualitative equalization of Georgian language with Greek. They were fully consistent with the hermeneutic principle reflected in poetics - a gradual move from free to precise translation, which was common among all the traditions of the Christian East. 